\title{
Holocene ostracod assemblages from the Co To Islands, northeastern Vietnam
}

\author{
Sota Niiyama ${ }^{1, a}$, Gengo Tanaka ${ }^{2}$, Toshifumi Komatsu ${ }^{3}$, Hung D. Doan ${ }^{4}$, Hung B. Nguyen ${ }^{4}$, Ha T. Trinh ${ }^{4}$, \\ and Minh T. Nguyen ${ }^{4}$ \\ ${ }^{1}$ Graduate School of Science and Technology, Kanazawa University, \\ Kakuma, Kanazawa City, Ishikawa 920-1192, Japan \\ ${ }^{2}$ Institute of Liberal Arts and Science, Kanazawa University, \\ Kakuma, Kanazawa City, Ishikawa 920-1192, Japan \\ ${ }^{3}$ Faculty of Advanced Science and Technology, Kumamoto University, 2-39-1, \\ Kurokami, Chuo-ku, Kumamoto 860-8555, Japan \\ ${ }^{4}$ Vietnam National Museum of Nature (VNMN), Vietnam Academy of Science and Technology, \\ 18 Hoang Quoc Viet, Hanoi, Vietnam \\ a formerly at: Graduate School of Science and Technology, Kumamoto University, \\ Kurokami, Chuo-ku, Kumamoto 860-8555, Japan \\ Correspondence: Sota Niiyama (niiyama@stu.kanazawa-u.ac.jp)
}

Received: 27 September 2018 - Revised: 22 December 2018 - Accepted: 30 January 2019 - Published: 18 June 2019

\begin{abstract}
In this study, we investigated ostracod assemblages from the Co To Islands in northeastern Vietnam. We identified 77 ostracod species belonging to 46 genera in nine surface sediment samples and recognized three biofacies (I, II, and III) based on Q-mode cluster analysis. The dominant species of biofacies I and II were Aurila hataii, Loxoconcha japonica, and Xestoleberis hanaii, which commonly occur in seaweed beds from southern China to Japan. This is the first report on the ostracod assemblage from the open-sea area in northeastern Vietnam. We clarified that the ostracod assemblages in the Gulf of Tongking, including northern Vietnam, have a strong biogeographical relationship with East Asia seas. A new species, Loxoconcha cotoensis sp. nov., was described herein from the Co To Islands (http://www.zoobank.org/NomenclaturalActs/ 41d3fb9f-ae17-4215-82c1-0874a8bf1a30, last access: 3 June 2019).
\end{abstract}

\section{Introduction}

The number of biogeographic and taxonomic studies of the ostracod assemblages dating from after the late Neogene in Southeast Asia has dramatically increased since the publication of the "Checklist of Ostracoda from Southeast Asia" by Hanai et al. (1980) (e.g., Whatley and Zhao, 1987a, 1988; Zhao and Whatley, 1989; Zhao and Wang, 1988; Gou, 1990; Mostafawi, 1992; Mostafawi et al., 2005; Tanaka et al., 2009, 2011b; Fauzielly et al., 2013; Yamada et al., 2014). The shallow-marine ostracod assemblages of Southeast Asia show extremely high diversity, especially those from after the late Neogene (Titterton and Whatley, 1988; Yasuhara et al., 2017). Investigation of Holocene shallowmarine ostracods from Southeast Asia plays an important role in the reconstruction of the paleobiogeography in the Indo-Pacific region after the late Neogene. However, information about Holocene ostracod assemblages from the IndoChinese peninsula is still lacking, even though this peninsula is located on the southeastern margin of the Eurasian continent, where a boundary defined by Titterton and Whatley (1988) exists. Ostracods are tiny Crustacea that are generally less than $1 \mathrm{~mm}$ in length. They have no planktonic larval stages and spend almost all of their time creeping on and/or burrowing in bottom sediments, or climbing on sea grasses or algae (Athersuch et al., 1989). Their distribution is strongly influenced by their environment and topography. One environmental variable, salinity, is an important factor which controls the distribution of estuarine and marginalmarine ostracods (Smith and Horne, 2002). Teeter (1973) 
suggested that benthic marine ostracods are transported by ocean currents on floating algae. His hypothesis has led to studies of the dispersal systems of the benthic marine ostracods (e.g., Titterton and Whatley, 1988; Jellinek, 1993). Vietnam has a long coastline that runs along the eastern margin of the Indo-Chinese peninsula, and two large rivers form large deltas along its coast, namely the Mekong river delta in southern Vietnam and the Red River delta in northern Vietnam. The ocean currents along the Vietnamese coast change direction from predominately northward in summer to southward in winter, which is due to the effects of the Asian monsoon. Some authors have described several late Cenozoic species in this region (Schneider, 1971; Herrig, 1976, 1977a, b, c, 1978). However, little is known about the distribution of Holocene ostracods from Vietnam. Tanaka et al. (2009) investigated shallow-marine ostracod assemblages from the coastal area of northern Vietnam. Tanaka et al. (2016) reported one interstitial species from Phu Quoc Island, southern Vietnam. However, information on open-marine ostracod assemblages from the coastal area of Vietnam is still unrevealed. The purpose of this study was to report the Holocene ostracod assemblages from the Co To Islands, northeastern Vietnam, and discuss their paleobiogeographic and paleoenvironmental significance.

\section{Regional setting, material, and methods}

\subsection{Regional setting}

The Co To Islands are located in the Gulf of Tongking in the northwestern part of the South China Sea. The outline of the Gulf of Tongking is crescent-shaped, and its depth is generally less than $60 \mathrm{~m}$. The Red River (Song Hong River) and some other rivers flow into the Gulf of Tongking and form deltas and estuaries. The Co To Islands are an archipelago located about $30 \mathrm{~km}$ offshore from the northeastern coast of Vietnam (Fig. 1). The Co To Islands consist of 40 islands. The main islands are the Co To Island, Thanh Lan Island, and Tran Island (Fig. 1).

\subsection{Material and methods}

The coastal areas of the Co To Islands are characterized by rocky shores and tidal flats. In this study, we collected surface sediments at 10 sites (Fig. 1, black stars; Table 1) by dredging with a skimming net sampler either from shore on tidal flats at low tide (at Sts. 1-4) or towing the sampler from a small boat (at Sts. 5-10). The sediments were immediately preserved in $70 \%$ ethyl alcohol and washed through $1 \mathrm{~mm}$ and $63 \mu \mathrm{m}$ sieves. After being completely dried, ostracod specimens were picked out under a stereoscopic microscope (Olympus SZX7). Specimens with a carapace, disarticulated valves, juvenile valves, and fragmented valves were also counted as one specimen. Ostracod specimens were identified under the stereoscopic microscope and photographed

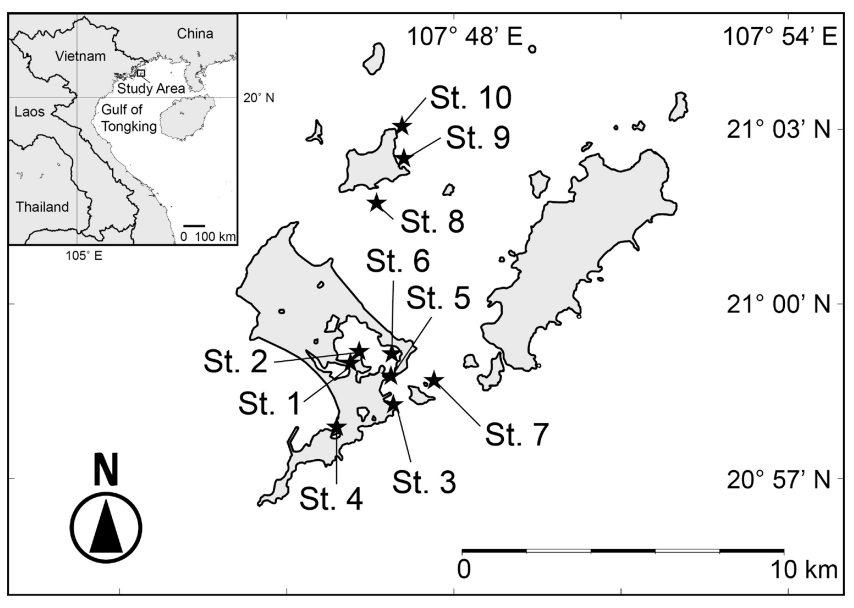

Figure 1. Map of the study area in the Co To Islands, indicating sampling sites (black filled stars); inset shows the location of the study area on the northeastern coast of Vietnam. The numbers of each station correspond to those in Table 1.

using a scanning electron microscope (Hitachi TM-1000, Tokyo, Japan; JEOL JSM-6360LV). We conducted a cluster analysis to clarify the similarities among ostracod assemblages from different sampled sites. We used six samples (Sts. 3, 5, 6, 7, 8, 9, and 10) at which more than 50 ostracod specimens occurred. Thirty-one species (significantly occurred below $5 \%$ rejection level) were used for the cluster analysis. Q-mode cluster analysis using the weighted pairgroup arithmetic average method was performed using the Horn's overlap index (Horn, 1966). Q-mode cluster analysis was calculated with the free software package Paleontological Statistics (PAST; Hammer, 2013). To clarify the biogeographical relationships among ostracod fauna, we compared the Holocene ostracod assemblages from the Co To Islands with assemblages from adjacent areas (Table 3 ). The areas and studies from which we extracted information were as follows: Australia (Hartmann, 1981; Howe and McKenzie, 1989; Warne et al., 2006), Strait of Malacca (Whatley and Zhao, 1987a, 1988; Yamada et al., 2014), Sunda Shelf (Zhao and Whatley, 1989; Mostafawi, 1992), southern China (Cai, 1982, 1988; Zheng, 1994; Hu and Tao, 2008), East China Sea (Zhao, 1984; Wang et al., 1988; Zhao and Wang, 1988; Tabuki and Nohara, 1990; Hu and Tao, 2008), and Japan (Tanaka et al., 1998; Irizuki et al., 2008; Tanaka, 2008). To reveal the similarity of ostracod assemblages in northeastern Vietnam, we calculated the value of the Jaccard similarity coefficient in terms of species $\left(J_{\mathrm{S}}\right)$ and genera $\left(J_{\mathrm{g}}\right)$ between the Co To Islands and the northeastern coast of Vietnam (Fig. 5). 
Table 1. Location and habitat information for the nine stations in this study.

\begin{tabular}{llllll}
\hline St. & Bottom sediment & Latitude & Longitude & Water depth & Remarks \\
\hline 1 & coarse sand & $20^{\circ} 59^{\prime} 03^{\prime \prime} \mathrm{N}$ & $107^{\circ} 45^{\prime} 55^{\prime \prime} \mathrm{E}$ & $0.5 \mathrm{~m}$ & sandy tidal flat (Channel), a few Saccostrea \\
2 & fine sand & $20^{\circ} 59^{\prime} 14^{\prime \prime} \mathrm{N}$ & $107^{\circ} 46^{\prime} 05^{\prime \prime} \mathrm{E}$ & $0.5 \mathrm{~m}$ & sandy tidal flat (Mangrove, Channel), Saccostrea, small gastropoda \\
3 & medium sand & $20^{\circ} 58^{\prime} 30^{\prime \prime} \mathrm{N}$ & $107^{\circ} 46^{\prime} 37^{\prime \prime} \mathrm{E}$ & $0.5 \mathrm{~m}$ & rocky shore, seaweed, intertidal zone, Saccostrea \\
4 & coarse sand & $20^{\circ} 57^{\prime} 58^{\prime \prime} \mathrm{N}$ & $107^{\circ} 45^{\prime} 35^{\prime \prime} \mathrm{E}$ & $0.5 \mathrm{~m}$ & rocky shore, seaweed, intertidal zone, Saccostrea \\
5 & fine sand & $20^{\circ} 58^{\prime} 57^{\prime \prime} \mathrm{N}$ & $107^{\circ} 46^{\prime} 46^{\prime \prime} \mathrm{E}$ & $2.5 \mathrm{~m}$ & midbay, shelly sand \\
6 & medium sand & $20^{\circ} 59^{\prime} 07^{\prime \prime} \mathrm{N}$ & $107^{\circ} 46^{\prime} 43^{\prime \prime} \mathrm{E}$ & $4.5 \mathrm{~m}$ & bay-mouth, fragmented shelly sand, algae \\
7 & medium sand & $20^{\circ} 58^{\prime} 48^{\prime \prime} \mathrm{N}$ & $107^{\circ} 47^{\prime} 17^{\prime \prime} \mathrm{E}$ & $6.5 \mathrm{~m}$ & offshore, fragmented shelly sand \\
8 & medium sand & $21^{\circ} 01^{\prime} 34^{\prime \prime} \mathrm{N}$ & $107^{\circ} 46^{\prime} 22^{\prime \prime} \mathrm{E}$ & $5 \mathrm{~m}$ & offshore, fragmented shelly sand, Bryozoa \\
9 & fine sand & $21^{\circ} 02^{\prime} 27^{\prime \prime} \mathrm{N}$ & $107^{\circ} 46^{\prime} 55^{\prime \prime} \mathrm{E}$ & $4 \mathrm{~m}$ & offshore, shelly sand \\
10 & coarse sand & $21^{\circ} 03^{\prime} 04^{\prime \prime} \mathrm{N}$ & $107^{\circ} 46^{\prime} 48^{\prime \prime} \mathrm{E}$ & $3.5 \mathrm{~m}$ & near sandbar, fragmented shelly sand \\
\hline
\end{tabular}

\section{Results}

\subsection{Ostracod assemblages and biofacies}

A total of 77 species were identified from nine samples from the Co To Islands (Table 2). Q-mode cluster analysis revealed three biofacies (I, II, and III), all bounded by a within-group similarity value of 0.5 (Fig. 2) as follows. Biofacies I: this biofacies was composed of four samples (Sts. 3, 6, 7, and 9), which were from rocky shore, bay-mouth, and offshore sites with depths of less than $6.5 \mathrm{~m}$. Aurila hataii and Loxoconcha japonica commonly occurred in this biofacies. Neonesidea elegans sensu lato (s.1.), Neonesidea sp. 1 and Xestoleberis hanaii also predominated in this cluster (Figs. 3, 4). The ratio of carapaces or living individuals present in these samples was relatively high, except for N. elegans s.l. and Neonesidea sp. 1. Biofacies II: this biofacies was represented by two samples (Sts. 8, 10), which were collected offshore at a depth of $5.0 \mathrm{~m}$ and also near a sandbar at a depth of $3.5 \mathrm{~m}$. It was characterized by the dominance of Xestoleberis hanaii. Also, other dominant species differ between the two samples: Propontocypris crocata in St. 8 Loxoconcha uranouchiensis in St. 10 (Figs. 3, 4). Biofacies III: this biofacies consisted of one sample (St. 5) from the midbay at a depth of $2.5 \mathrm{~m}$. This biofacies was dominated by Caudites huyeni and Loxoconcha cotoensis sp. nov. Species Tanella glacilis s.l. and Loxoconcha vietnamensis (Figs. 3,4 ) are also characterized by this biofacies. The total ratio of living individuals to all specimens was relatively high (about $50 \%$ ) in biofacies III. Whole synonym list of dominant species is shown in the Supplement.

\subsection{Comparison with ostracod assemblages of adjacent areas}

Table 3 shows the distributions of 43 species that have been reported in Holocene materials from the Co To Islands and its adjacent areas. Three species (Caudites huyeni, Cornucoquimba gibboidea, and Loxoconcha vietnamensis) were excluded from this comparison because they occurred at the northeastern coast of Vietnam only in Holocene and late
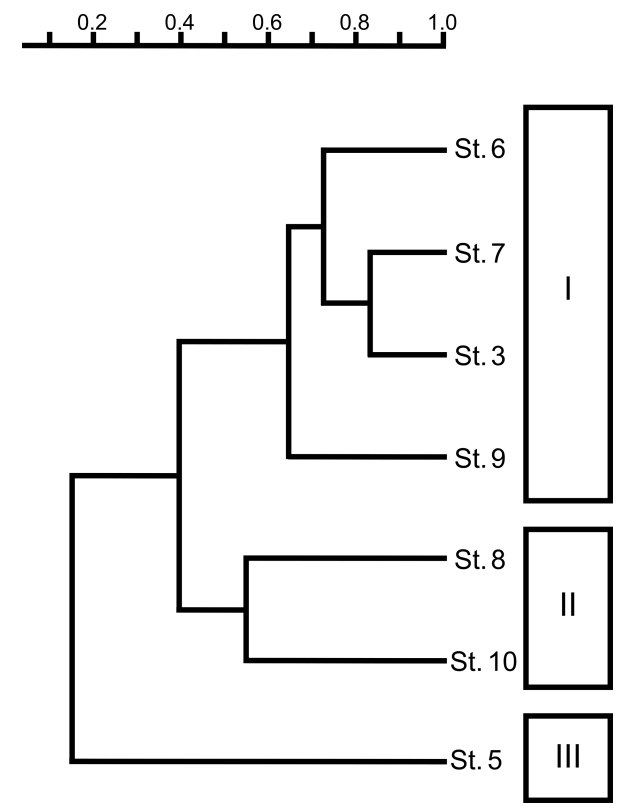

Figure 2. Dendrogram of Q-mode cluster analysis showing the three different biofacies (I, II, and III).

Holocene materials (e.g., Tanaka et al., 2009, 2011b). The remaining species were used for further analysis of the faunal assemblage in the Gulf of Tongking. Thirty-seven species from the Co To Islands have also been reported from southern China (Cai, 1982, 1988; Zhao and Wang, 1988; Gou, 1990; Zheng, 1994; Hu and Tao, 2008). Twenty-seven species from the Co To Island are found in the East China Sea (Zhao, 1984; Zhao and Wang, 1988; Tabuki and Nohara, 1990; Zhou, 1995; Hu and Tao, 2008). Three species (Keijia demissa s.l., Kotoracythere inconspicua s.l., and Robustaurila splendideornata) widely occur in the west Pacific region (Australia, Strait of Malacca, Sunda Shelf, Vietnam, southern China, and East China Sea). Among them, $K$. demissa s.l. and $K$. inconspicua s.l. are known to be stenothermal species, which have an extremely wide habitat across the Indo-Pacific Ocean and in Australia (Teeter, 1973; Titterton and Whatley, 1988; Zhao and Whatley, 1989). Eleven species (Aurila cymba, 
Table 2. List of ostracod species from the Co To Islands. Bold numbers indicate species that included living specimens.

\begin{tabular}{|c|c|c|c|c|c|c|c|c|c|c|}
\hline Species & St. 1 & St. 3 & St. 4 & St. 5 & St. 6 & St. 7 & St. 8 & St. 9 & St. 10 & Total \\
\hline Aurila cymba (Brady, 1869) & & 4 & 2 & & 32 & 7 & & 1 & & 46 \\
\hline Aurila hataii (Ishizaki, 1968) & & 20 & 3 & 3 & 78 & 27 & & 27 & 8 & 166 \\
\hline Bicornucythere bisanensis s.l. (Okubo, 1975) & & 5 & 4 & 2 & 5 & 2 & 1 & 3 & 1 & 23 \\
\hline Bythoceratina cassidoidea (Zhao in Wang et al., 1988) & & & & & & 1 & & & & 1 \\
\hline Bythoceratina sp. & & & & & & & 1 & & 1 & 2 \\
\hline Callistocythere asiatica (Zhao, 1984) & & 5 & & & 2 & 3 & & 5 & 2 & 17 \\
\hline Callistocythere tientaolis (Hu and Tao, 2008) & & & & & & & & 1 & & 1 \\
\hline Callistocythere sp. & & & & & & & 4 & 1 & & 5 \\
\hline Cathaycythere reticulata (Whatley and Zhao, 1987a) & & 2 & & & 1 & 8 & 1 & 2 & 4 & 18 \\
\hline Caudites huyeni (Tanaka et al., 2009) & & & 1 & 57 & & 2 & & & 10 & 70 \\
\hline Caudites scopulicola (Hartmann,1981) & & & & & & & 1 & & & 1 \\
\hline Chinocythere sp. & & & & 1 & & & & & 1 & 2 \\
\hline Coquimba aff. ishizakii (Yajima, 1978) & & 3 & & 1 & 7 & 6 & 4 & 4 & 8 & 33 \\
\hline Cornucoquimba gibboidea (Hu, 1982) & & 1 & & & & & & & & 1 \\
\hline Cornucoquimba subgibba $(\mathrm{Hu}, 1982)$ & & & 3 & & & 2 & & & & 5 \\
\hline Cythere omotenipponica (Hanai, 1959b) & & 1 & & 1 & 20 & 3 & & & & 25 \\
\hline Cytherura sp. & & & & 1 & & & & & 1 & 2 \\
\hline Danipussella sp. & & & & & & & & 1 & & 1 \\
\hline Hemicythere variornata (Hartmann, 1978) & & & & & 1 & 2 & & & & 3 \\
\hline Hemicytheridea reticulata (Kingma, 1948) & & & 1 & & & & & & 1 & 2 \\
\hline Hemicytherula huangi (Kaseda and Ikeya in Tanaka et al., 2011a) & & 1 & & & & & & & & 1 \\
\hline Hermanites deltoides (Brady, 1890) & & & & & & & & & 2 & 2 \\
\hline Hermanites transoceanica s.l. (Teeter, 1975) & & & & & & & & 1 & & 1 \\
\hline Ishizakiella cf. miurensis (Hanai, 1957a) & & 1 & & & & 3 & & & 3 & 7 \\
\hline Javanella kendengensis (Kingma, 1948) & & & & & & 1 & & & 10 & 11 \\
\hline Keijella kloempritensis (Kingma, 1948) & & & & & 1 & & & & & 1 \\
\hline Keijia demissa s.1. (Brady, 1868) & & & & & 1 & 1 & & & 2 & 4 \\
\hline Kotoracythere inconspicua s.1. (Brady, 1880) & & 1 & & & & & 1 & & 2 & 4 \\
\hline Loxoconcha japonica (Ishizaki, 1968) & & 10 & 1 & & 12 & 25 & 1 & 28 & 24 & 101 \\
\hline Loxoconcha kattoi (Ishizaki, 1968) & & 1 & & & & 1 & & & & 2 \\
\hline Loxoconcha malayensis (Zhao and Whatley, 1989) & & & 2 & 4 & 5 & 3 & 1 & 7 & 1 & 23 \\
\hline Loxoconcha ocellata $(\mathrm{Ho}, 1982)$ & & 1 & & & & & & & & 1 \\
\hline Loxoconcha cotoensis $\mathrm{n} . \mathrm{sp}$. & & & 3 & 50 & & & & 13 & & 66 \\
\hline Loxoconcha uranouchiensis (Ishizaki, 1968) & & & 3 & 2 & & 4 & & & 43 & 52 \\
\hline Loxoconcha vietnamensis (Tanaka et al., 2009) & & & 1 & 25 & & & & & 2 & 28 \\
\hline Loxoconcha sp. & & & & & & & & 1 & & 1 \\
\hline Mydionobardia sp. & & & & & & & 4 & & & 4 \\
\hline Neocytheretta horrida (Mostafawi, 1992) & & & & & 2 & & & & & 2 \\
\hline Neocytheretta murilineata (Zhao and Whatley, 1989) & & & 1 & & & & & & & 1 \\
\hline Neocytheromorpha longa (Guan, 1978) & & 1 & & & & & & & & 1 \\
\hline Neomonoceratina delicata (Ishizaki and Kato, 1976) & & & 1 & & & 1 & & & & 2 \\
\hline Neonesidea elegans s.l. (Brady, 1869) & & 1 & & & 17 & 15 & & 7 & & 40 \\
\hline Neonesidea sp. 1 & & 26 & & & & 17 & 1 & 1 & & 45 \\
\hline Neonesidea sp. 2 & & & & & & 2 & & & 2 & 4 \\
\hline Paracathaycythere costaereticulata (Whatley and Zhao, 1991) & & 1 & 3 & 1 & & & & & & 5 \\
\hline Paracypris sp. & & & & & & & 2 & & & 2 \\
\hline Paracytheridea sp. 1 & & 1 & & & & & & & 1 & 2 \\
\hline Paracytheridea reunionensis (Whatley and Keelar, 1989) & & & & & & & & & 2 & 2 \\
\hline Paracytherois cf. tosaensis (Ishizaki, 1968) & & & 2 & 6 & & & 6 & & 2 & 16 \\
\hline Paradoxostoma sp. & 1 & & & & & & & & & 1 \\
\hline Paradoxostoma sp. 2 & & & 2 & & & & & & & 2 \\
\hline Paradoxostoma sp. 3 & & & & & & & 1 & & & 1 \\
\hline Paradoxostoma sp. 4 & & & & & & 1 & & & 1 & 2 \\
\hline Parakrithella pseudadonta (Hanai, 1959a) & & & & & & & & & 1 & 1 \\
\hline Paratanella sp. & & & 2 & & & & & & 1 & 3 \\
\hline Phlyctenophora sp. & & & & & & & 1 & & & 1 \\
\hline Pistocythereis bradyformis (Ishizaki, 1968) & & 1 & 2 & 2 & 2 & & & & & 7 \\
\hline Pistocythereis bradyi (Ishizaki, 1968) & & & & & 9 & 6 & & 8 & 1 & 24 \\
\hline Pistocythereis cribriformis (Brady, 1866) & & & & & & 1 & & & & 1 \\
\hline
\end{tabular}


Table 2. Continued.

\begin{tabular}{|c|c|c|c|c|c|c|c|c|c|c|}
\hline Species & St. 1 & St. 3 & St. 4 & St. 5 & St. 6 & St. 7 & St. 8 & St. 9 & St. 10 & Total \\
\hline Pistocythereis euplectella (Brady, 1869) & & & & & & 1 & & & & 1 \\
\hline Pontocythere granulata (Guan, 1981) & & & & & & 1 & 2 & & 2 & 5 \\
\hline Pontocythere miurensis (Hanai, 1959a) & & 2 & 1 & & 8 & 3 & & 4 & & 18 \\
\hline Pontocythere subjaponica (Hanai, 1959a) & & 2 & 1 & & 2 & 6 & & 67 & 8 & 86 \\
\hline Propontocypris crocata (Maddocks, 1969) & & & & & & 4 & 34 & & 2 & 40 \\
\hline Propontocypris sp. & & & & & & & & 1 & & 1 \\
\hline Pseudocythere aff. frydli (Yajima, 1982) & & & & & & 2 & 26 & 1 & & 29 \\
\hline Robustaurila splendideornata (Hartmann, 1974) & & 2 & & & 17 & 8 & & 22 & 6 & 55 \\
\hline Semicytherura cf. miurensis (Hanai, 1957a) & & 1 & & & & & & 2 & 2 & 5 \\
\hline Semicytherura sp. & & & & & & & & & 1 & 1 \\
\hline Sinocythere sp. & & 1 & & & & & & & & 1 \\
\hline Stigmatocythere cf. bona (Chen in Hou et al., 1982) & & 2 & 2 & & 2 & 5 & 2 & 1 & 9 & 23 \\
\hline Tanella gracilis s.l. (Kingma, 1948) & & 1 & & 34 & 2 & 3 & & & 6 & 46 \\
\hline Tanella cf. zebra (Hou and Tao, 2008) & & & 1 & 14 & & & & & & 15 \\
\hline Tanella sp. & & & 3 & 3 & & & & & & 6 \\
\hline Triebelina $\mathrm{sp}$. & & 1 & & & & & & & & 1 \\
\hline Xestoleberis hanaii (Ishizaki, 1968) & & 7 & 2 & & 13 & 36 & 121 & 6 & 79 & 264 \\
\hline Xestoleberis sp. & & & & & & & & & 1 & 1 \\
\hline No. of specimens & 1 & 106 & 47 & 207 & 239 & 213 & 215 & 215 & 253 & 1496 \\
\hline No. of species & 1 & 28 & 25 & 17 & 23 & 35 & 21 & 25 & 37 & \\
\hline
\end{tabular}

Aurila hataii, Bicornucythere bisanensis s.1., Bythoceratina cassidoidea, Callistocythere asiatica, Cythere omotenipponica, Loxoconcha japonica, Loxoconcha kattoi, Loxoconcha ocellata, Loxoconcha uranouchiensis, and Pontocythere miurensis) have been distributed in East Asia (southern China, East China Sea, and Japan). In summary, the ostracod assemblage from the Co To Islands is most closely similar to that of the southern China one.

\section{Discussion}

\subsection{Comparison with previous studies}

To investigate the relationships between characteristic ostracod species of the Co To Islands and its adjacent areas, we focused on the dominant species of three ostracod biofacies (I-III). The dominant species (Aurila hataii and Loxoconcha japonica) of Biofacies I live on seaweed and algae in the littoral zone (Kamiya, 1988; Nakao et al., 2001). These two species are widely distributed along the coasts of Japan and China (e.g., Ishizaki, 1968, 1971; Wang et al., 1988; Ruan, 1990; Masuma and Yamada, 2014). In terms of fossil records, Biofacies I is similar to cluster II of the Shimajiri Group reported by Tanaka and Nomura (2009). Xestoleberis hanaii is the most abundant species in Biofacies II. X. hanaii lives on calcareous algae on intertidal rocky shores, around Zostera beds, and Sargassum beds (Okubo, 1984; Kamiya, 1988; Ikeya and Kato, 2000). In the Co To Islands, X. hanaii lives around Sargassum beds. X. hanaii has been reported in Japan and China (Kamiya et al., 2001; Nakao et al., 2001; Irizuki et al., 2006; Wang et al., 1988). The species composing Biofacies III (St. 5) is similar to the northeastern coast of Vietnam (Sts. 14 and 15 of Tanaka et al., 2009). We com- pared the differences in faunal composition among the Co To Islands and the northeastern coast of Vietnam by using the Jaccard similarity coefficient $(J)$. The results revealed that the assemblages of the Co To Islands showed low similarity to that of the northeastern coast of Vietnam $\left(J_{\mathrm{s}}=0.16\right.$, $\left.J_{\mathrm{g}}=0.39\right)$. The fauna of the Co To Islands and the northeastern coast of Vietnam were less similar than might be expected, although these two areas are relatively close (shortest distance is about $35 \mathrm{~km}$ between St. 4 of this study and St. 15 of Tanaka et al., 2009). In the Co To Islands, the ratio of phytal species to the total number of specimens is quite high. On the other hand, the number of species which live in a wide range of salinity such as Sinocytheridea impressa is low or the species is absent in the Co To Islands.

\subsection{Relationships among biogeographic provinces}

The result of biogeographic comparison showed that the ostracod assemblage in the Co To Islands has a strong connection with the East Asia seas (Table 3). Our report supports the opinion of Tanaka et al. (2009) that the northern Vietnamese shallow-marine ostracod fauna belongs to the Kymerian Provence of Titterton and Whatley (1988), even for islands situated in open-sea areas. Although, the ostracod assemblage in Weizhou Island is reported by Ruan (1990) (Fig. 5). The ostracod assemblage in Weizhou Island is characterized by the dominance of Loxoconcha japonica, Robustaurila splendideornata, and Loxoconcha alata. In addition to these three species, some phytal species, such as $A u$ rila hataii, Neonesidea elegans s.1., and Xestoleberis hanaii, are also common there, and these species also occurred commonly in the Co To Islands and some other Kymerian 
Table 3. Biogeographical distribution of the 43 species detected in the Co To Islands.

\begin{tabular}{|c|c|c|c|c|c|c|c|}
\hline References & $2,3,4$ & $5,6,7$ & $8,9,10$ & $11,12,13,14,15,16$ & $15,16,17,18,19$ & $19,20,21,22$ & \\
\hline Species & Australia & $\begin{array}{l}\text { Strait of } \\
\text { Malacca }\end{array}$ & $\begin{array}{l}\text { Sunda } \\
\text { Shelf }\end{array}$ & $\begin{array}{l}\text { Southern } \\
\text { China }\end{array}$ & $\begin{array}{c}\text { East } \\
\text { China } \\
\text { Sea }\end{array}$ & Japan & References \\
\hline Caudites scopulicola & * & & & & & & 3 \\
\hline Neocytheretta horrida & $*$ & & * & & & & 4,9 \\
\hline Hermanites transoceanica s. 1 . & $*$ & & & $*$ & * & & $2,13,14,18$ \\
\hline Hemicythere variornata & $*$ & & * & * & & & $2,3,4,8,13$ \\
\hline Keijella kloempritensis & * & * & & * & & & $4,5,7,14$ \\
\hline Tanella glacilis s. 1. & $*$ & * & $*$ & * & & & $2,3,7,8,11,12,13,14,16$ \\
\hline Keijia demissa s. 1. & $*$ & $*$ & * & * & $*$ & & $3,4,5,8,9,13,14,18$ \\
\hline Robustaurila splendideornata & $*$ & $*$ & * & $*$ & $*$ & & $3,4,6,8,13,15$ \\
\hline Kotoracythere inconspicua s. 1. & $*$ & $*$ & * & * & $*$ & * & $1,4,8,13,16,18,19$ \\
\hline Neocytheretta murilineata & & $*$ & * & * & & & $6,7,8,12$ \\
\hline Pistocythereis cribriformis & & $*$ & * & * & & & $5,8,9,10,14$ \\
\hline Hemicytheridea reticulata & & $*$ & * & * & $*$ & & $7,8,11,16,17$ \\
\hline Neomonoceratina delicata & & $*$ & * & * & $*$ & & $5,7,8,9,10,14,16$ \\
\hline Pistocythereis euplectella & & $*$ & * & * & $*$ & & $5,8,9,10,14,16$ \\
\hline Parakrithella pseudadonta & & $*$ & * & * & $*$ & * & $5,8,9,10,11,14,16,19,21$ \\
\hline Pistocythereis bradyi & & * & * & * & $*$ & * & $5,8,9,10,11,14,15,16,17,18,19,20,21,22$ \\
\hline Pontocythere subjaponica & & $*$ & * & * & $*$ & $*$ & $5,8,12,14,15,16,18,19,20,21,22$ \\
\hline Cornucoquimba subgibba & & & $*$ & & & & 9 \\
\hline Pontocythere granulata & & & * & & & & 8,9 \\
\hline Hermanites deltoides & & & * & * & & & 10,13 \\
\hline Javanella kendengensis & & & * & * & & & $8,9,11,14$ \\
\hline Loxoconcha malayensis & & & * & * & & & 8,12 \\
\hline Pistocythereis bradyformis & & & * & * & $*$ & * & $9,11,12,14,15,16,17,19,21,22$ \\
\hline Xestoleberis hanaii & & & * & * & $*$ & * & $8,9,11,12,14,15,17,19,21,22$ \\
\hline Callistocythere tientaolis & & & & * & & & 16 \\
\hline Hemicytherura huangi & & & & * & & & 16 \\
\hline Paracytheridea reunionensis & & & & $*$ & & & 16 \\
\hline Cathaycythere reticulata & & & & * & $*$ & & 14,16 \\
\hline Neocytheromorpha longa & & & & * & $*$ & & $14,15,16$ \\
\hline Neonesidea elegans s. 1. & & & & * & $*$ & & $13,14,15,16,17$ \\
\hline Aurila cymba & & & & * & $*$ & * & $11,12,14,16,17,17,20,21$ \\
\hline Aurila hataii & & & & * & $*$ & $*$ & $13,14,16,19,21,22$ \\
\hline Bicornucythere bisanensis s. 1. & & & & $*$ & $*$ & $*$ & $11,14,15,16,17,20,21$ \\
\hline Bythoceratina cassidoidea & & & & * & * & * & $12,14,15,16,19,22$ \\
\hline Callistocythere asiatica & & & & $*$ & $*$ & $*$ & $12,16,17,19,21$ \\
\hline Cythere omotenipponica & & & & * & $*$ & * & $11,14,16,17,19,21,22$ \\
\hline Loxoconcha japonica & & & & * & $*$ & * & $11,14,16,19,21$ \\
\hline Loxoconcha kattoi & & & & * & $*$ & * & $14,15,16,19,21,22$ \\
\hline Loxoconcha ocellata & & & & * & $*$ & * & $8,15,22$ \\
\hline Loxoconcha uranouchiensis & & & & * & $*$ & * & $14,15,16,19,20,21,22$ \\
\hline Pontocythere miurensis & & & & * & $*$ & $*$ & $11,14,16,19,20,21,22$ \\
\hline Paracathaycythere costaereticulata & & & & & $*$ & * & 16,21 \\
\hline Propontocypris crocata & & & & & & $*$ & 22 \\
\hline Number of common species & 9 & 13 & 20 & 37 & 27 & 19 & \\
\hline Ratio of common species (\%) & 21 & 30 & 47 & 86 & 63 & 44 & \\
\hline
\end{tabular}

* Indicate the species reported from each area. References: (1) Witte and Harten (1991); (2) Hartmann (1981); (3) Howe and McKenzie (1989); (4) Warne et al. (2006); (5) Whatley and Zhao (1987a); (6) Whatley and Zhao (1988); (7) Yamada et al. (2014); (8) Zhao and Whatley (1989); (9) Mostafawi (1992); (10) Ramlan and Noraswana (2010); (11) Cai (1982); (12) Cai (1988); (13) Gou (1990); (14) Zheng (1994); (15) Zhao and Wang (1988); (16) Hu and Tao (2008); (17) Zhao (1984); (18) Tabuki and Nohara (1990); (19) Zhou (1995); (20) Tanaka et al. (1998); (21) Irizuki et al. (2008); (22) Tanaka (2008).

Province areas. The results show that the ostracod assemblages in the Gulf of Tongking, including northern Vietnam, have little relationship with tropical fauna in the East Indian Province.

\subsection{The ostracod assemblages of the Co To Islands as environmental indicators}

The present results are also useful for the reconstruction of the paleoenvironment in the coast of the Indo-Chinese peninsula. For example, Tanaka et al. (2011b) investigated the transitions of the ostracod assemblage about 10000 years based on three sediment cores in the Red River delta, northeastern coast of Vietnam, and reconstructed past sealevel changes. They reported that the open-marine ostra- cods were detected during the period of maximum sea levels, and the assemblages at this time were characterized by Loxoconcha malayensis, Pistocythereis bradyformis, Pistocythereis bradyi, Pistocythereis euplectella, Pistocythereis cribriformis, and Cytherelloidea cingulata. These species are common in the southern coast of the Indo-Chinese peninsula, but rare in the Co To Islands (especially $C$. cingulata and $P$. euplectella, which do not occur at the islands). The ostracod assemblages from the Co To Islands could thus serve as environmental indicators representing the conditions in littoral areas with argal/seaweeds in the eastern or southeastern margin of the Eurasian continent, especially during the Quaternary. 


\section{Systematic paleontology}

Family: Loxoconchidae Sars, 1925

Genus: Loxoconcha Sars, 1866

Loxoconcha cotoensis sp. nov. (Figs. 4: (4), 6: 7)

Derivation of name

From type locality, Co To Island.

Holotype

Adult female carapace (VNMN.0099), (Fig. 6, 1-6)

\section{Paratypes}

One adult male carapace (VNMN.0100), (Fig. 6: 7-12), one adult male left valve (VNMN.0088), (Fig. 4: 4), one A-1 instar female right valve (VNMN.0101), one A-1 instar male carapace (VMNH.0102), one adult female carapace (divided into left and right valve for dissection and internal observation) (VNMN.0103), (Fig. 7: 1); female antenna (VNMN.0104), antennule, mandible, maxilla, first leg, second leg, and third leg (VNMN.0105), male copulatory organ (VNMN.0106).

\section{Type locality}

Holocene fine sand from the Co To Islands, northeastern Vietnam (St. 5; $20^{\circ} 58^{\prime} 57^{\prime \prime} \mathrm{N}, 107^{\circ} 46^{\prime} 46^{\prime \prime} \mathrm{E}$ )

\section{Dimensions}

Female (holotype) (VNMN.0099), $L=374 \mu \mathrm{m}$, $H=226 \mu \mathrm{m}$; female (aratype) (VNMN.0103), $L=379 \mu \mathrm{m}$, $H=227 \mu \mathrm{m}$; female, A-1 instar (paratype) (VNMN.0101), $L=329 \mu \mathrm{m}, H=199 \mu \mathrm{m}$; male (paratype) (VNMN.0100), $L=450 \mu \mathrm{m}, \quad H=224 \mu \mathrm{m}$; (VNMN.0088), $L=441 \mu \mathrm{m}$, $H=218 \mu \mathrm{m}$; male, A-1 instar (paratype) (VMNH.102), $L=356 \mu \mathrm{m}, H=199 \mu \mathrm{m}$.

\section{Diagnosis}

Small subrhomboidal-shaped Loxoconcha with widely arched anterior margin, straight dorsal margin. Surface covered by punctuation and characterized by trifurcated muri at anteroventral area. Male copulatory appendage with funeralbell-like clasping apparatus, ox-shaped distal lobe and copulatory duct being short with a tapered distal end.

\section{Description}

Outer morphology of carapace (Fig. 6: 1-14). Carapace subrhomboidal in lateral view; anterior margin broadly arched toward anteroventral direction, dorsal margin straight, posterior margin broadly rounded toward posteroventral direction, ventral margin sinuated and concaved at one-third from anterior end. Surface ornamented with punctation. Three muri run parallel from anterior to midventral margin, most dorsal one trifurcated at anteroventral area. Eye tubercle prominent. Caudal process absent. Ellipsoidal in dorsal view, Ovate in anterior view. Strong sexual dimorphism: female shorter and rounder in lateral view. A-1 instar: ventral muri are unclear. Prominent sexual dimorphism; male is longer than female, weak punctation of posteroventral area of male.

Inner morphology of valve (Fig. 7: 1, 2). Marginal pore canal straight: nine in anterior, five in ventral, and five posterior pore canals. Duplicature developed. Anterior vestibulum developed. Hinge gongylodont: left valve anterior element a rounded tooth, median element an elongate bar, posterior element an elongated socket with a stepped tooth. One heart shaped frontal scar. Four adductor muscle scars in a vertical low: upper most one is rounded, second and lower most scars are oblong, third one is kidney shaped. Two oblong mandible scars at anteroventral area of adductor muscle scars.

Antennula (Fig. 7: 3). Five articulated podomeres, length ratio among them from proximal to distal $80: 24: 19$ : $25: 40$. Walls well developed, especially first to fourth podomeres. First podomere with simple seta at posterior distal end, pseudochaetae at anterior proximal end, and very short setulae along anterior margin. Second podomere with stout simple seta at anterior distal end. Third podomere with simple seta and claw-like seta at anterior distal end. Fourth podomere with two simple setae and one stout seta at anterior distal end, one long simple seta at posterior distal end. Fifth podomere with four setae at distal end, two simple setae with different length, one claw-like seta, one spoon-like seta.

Antenna (Fig. 7: 4). Four articulated podomeres, length ratio among them from proximal to distal $48: 20: 50: 5$. First podomere with several pseudochaetae at anterior distal end. Second podomere with exopodite (meaning spinneret seta) at distal end, one plumose seta at posterior distal end, pseudochaetae at midanterior margin. Third podomere with simple seta at posterior distal end, two setae with different length at middle part of the posterior margin (short simple seta and long plumose seta), pseudochaetae along posterior margin from the distal part of the two setae to the distal end, and several pseudochaetae (two distal pseudochaetae longer than other pseudochaetae) near anterior proximal end. Fourth podomere with two stout claw-like setae.

Mandibula (Fig. 7: 5). Five articulated podomeres: length ratio among them from proximal to distal $20: 7: 3: 3: 1$. First podomere (coxa) bearing six teeth to distal end. Second podomere (basis) with five simple setae on proximal mar- 


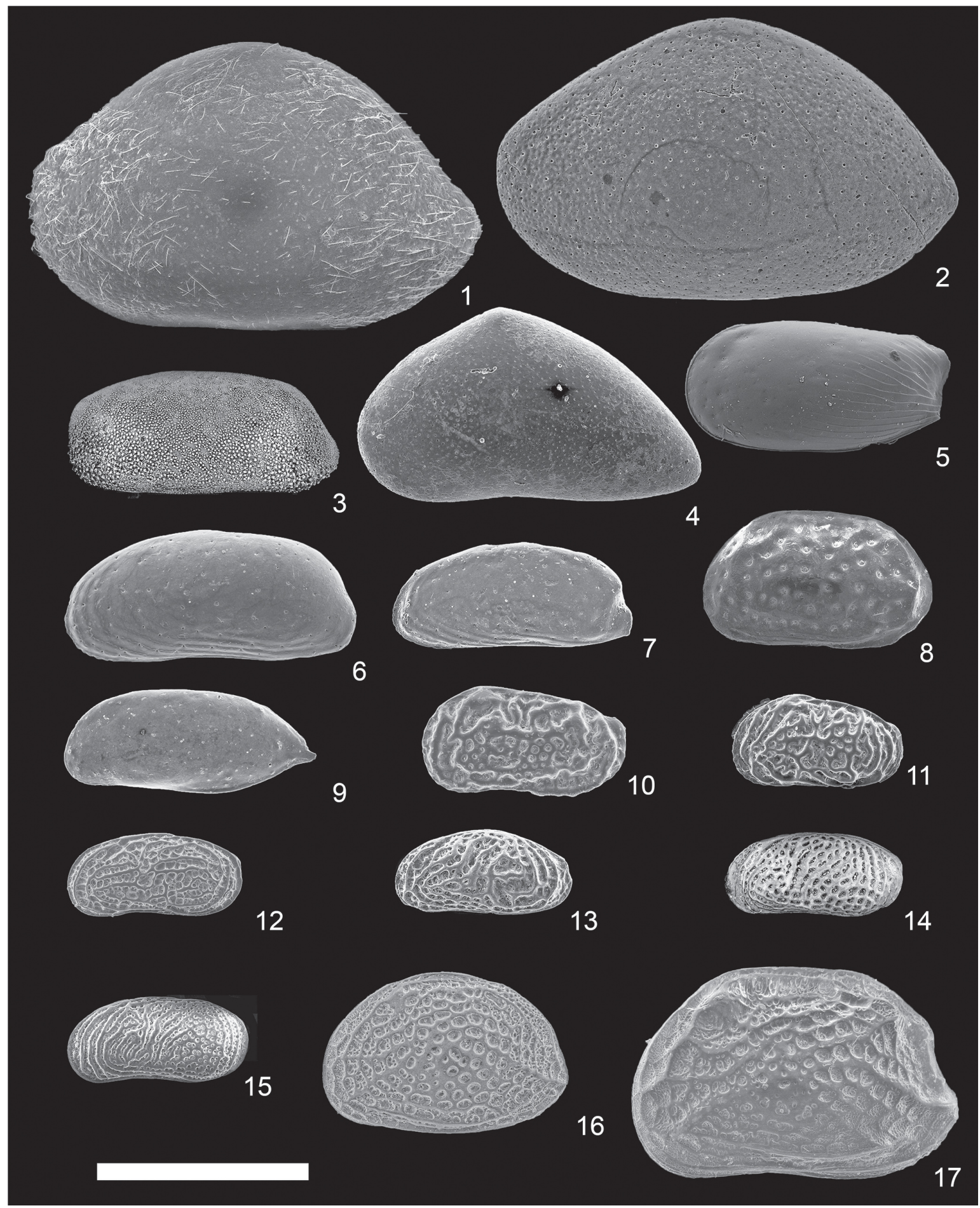

Figure 3. Scanning electron photomicrographs of the characteristic species in the Co To Islands. All specimens shown are the left valves. Scale bar is $500 \mu \mathrm{m}$. (1) Neonesidea elegans s.l. (Brady, 1869) (from St. 6) (VNMN.0068); (2) Neonesidea sp. 1 (from St. 3) (VNMN.0069); (3) Mydionobairdia sp. (from St. 8) (VNMN.0070); (4) Propontocypris crocata (Maddocks, 1969) (from St. 8) (VNMN.0071); (5) Pseudocythere aff. frydli (Yajima, 1982) (from St. 8) (VNMN.0072); (6) Pontocythere miurensis (Hanai, 1959a) (from St. 9) (VNMN.0073); (7) Pontocythere subjaponica (Hanai, 1959a) (from St. 3) (VNMN.0074); (8) Cythere omotenipponica (Hanai, 1959b) (from St. 6) (VNMN.0075); (9) Javanella kendengensis (Kingma, 1948) (from St. 10) (VNMN.0076); (10) Callistocythere asiatica (Zhao, 1984) (from St. 9) (VNMN.0077); (11) Callistocythere sp. (from St. 8) (VNMN.0078); (12) Ishizakiella cf. miurensis (Hanai, 1957a) (from St. 7) (VNMN.0079); (13) Tanella gracilis s.l. (Kingma, 1948) (from St. 5) (VNMN.0080); (14) Tanella cf. zebra (Hu and Tao, 2008) (from St. 5) (VNMN.0081); (15) Tanella sp. (of Tanaka et al., 2009) (from St. 5) (VNMN.0082); (16) Aurila cymba (Brady, 1869) (from St. 6) (VNMN.0083); (17) Aurila hataii (Ishizaki, 1968) (from St. 6) (VNMN.0084). 




Figure 4. Scanning electron photomicrographs of the characteristic species in the Co To Islands. All specimens shown are the left valves. Scale bar is $500 \mu \mathrm{m}$. (1) Caudites huyeni (Tanaka et al., 2009) (from St. 6) (VNMN.0085); (2) Coquimba aff. ishizakii (Yajima, 1978) (from St. 6) (VNMN.0086); (3) Robustaurila splendideornata (Hartmann, 1974) (from St. 9) (VNMN.0087); (4) Loxoconcha cotoensis sp. nov. (from St. 5) (VNMN.0088); (5) Loxoconcha japonica (Ishizaki, 1968) (from St. 6) (VNMN.0089); (6) Loxoconcha malayensis (Zhao and Whatley, 1989) (from St. 6) (VNMN.0090); (7) Loxoconcha uranouchiensis (Ishizaki, 1968) (from St. 7) (VNMN.0091); (8) Loxoconcha vietnamensis (Tanaka et al., 2009) (from St. 5) (VNMN.0092); (9) Bicornucythere bisanensis s. 1. (Okubo, 1975) (from St. 3) (VNMN.0093); (10) Cathaycythere reticulata (Whatley and Zhao, 1987b) (from St. 6) (VNMN.0094); (11) Pistocythereis bradyi (Ishizaki, 1968) (from St. 6) (VNMN.0095); (12) Stigmatocythere cf. bona (Chen in Hou et al., 1982) (from St. 7) (VNMN.0096); (13) Paracytherois cf. tosaensis (Ishizaki, 1968) (from St. 8) (VNMN.0097); (14) Xestoleberis hanaii (Ishizaki, 1968) (from St. 8) (VNMN.0098). 




Figure 5. Map of the Gulf of Tongking with isobaths plotted. Labels A-C are the sites of studies of ostracod assemblages: A: The Co To Islands (this study); B: northeastern coast of Vietnam (Tanaka et al., 2009); C: Weizhou Island (Ruan, 1990).

gin. Third podomere with two simple setae at posterior distal end and one feather-like seta at anterior distal end. Fourth podomere with five simple setae at anterior distal end, two short plumose setae at middle of posterior margin, and one stout simple seta at posterior distal end. Fifth podomere with five unequal simple setae at distal end.

Maxillula (Fig. 7: 6). Extremely thin branchial plate (exopodite) with 16 plumose setae. Basal podomere bearing palp and three endites. Palp with two indistinct podomeres; first podomere with four long plumose setae at distal end, second podomere with three stout setae at distal end and one stout seta at proximal end. Outer masticatory process with four simple setae and one plumose seta at distal end. Middle and inner masticatory processes with six simple setae.

Fifth limb (Fig. 7: 7). Four articulated podomeres: length ratio among them from proximal to distal $100: 57: 28: 37$. First podomere with two plumose setae at dorsal distal end, and two simple setae at half way from distal end of anterior margin. Third podomere with one knob-like structure at anterior distal end. Fourth podomere with stout distal claw.

Sixth limb (Fig. 7: 8). Four articulated podomeres: length ratio among them from proximal to distal $98: 77: 35: 42$. First podomere with two plumose setae at middle of dorsal margin, one short plumose seta at anterior distal end, and one plumose seta at posterior proximal end. Second podomere with simple seta at anterior distal end. Fourth podomere with stout distal craw.

Seventh limb (Fig. 7: 9). Four articulated podomeres, length ratio among them from proximal to distal 120:94: $35: 50$. First podomere with one plumose seta at anterior distal end, one plumose seta at half way from distal end of anterior margin, one plumose seta at outer lateral surface of half way from distal end, one plumose seta at posterior proximal end. Second podomere with simple seta at anterior distal end.

Male Copulatory appendage (Fig. 7: 10). Capsule trapezoidal and wall, well developed along margin. Ox-like distal lobe developed on distal end of capsule. One funeral-bell-like clasping apparatus. Copulatory duct short, one turn around, tapered distal end.

\section{Remarks}

Loxoconcha cotoensis sp. nov. is similar to Loxoconcha taiwanensis Zhao (1988) in Wang et al. (1988) from the Holocene surface sediment of the East China Sea in terms of its broadly arched posterior margin, but differs from it by its widely arched anterior margin, trifurcated muri, and surface ornamentation being covered by punctuation. The new species resembles Loxoconcha pulchra Ishizaki (1968) from the Holocene sediments of Uranouchi Bay, Shikoku Island, Japan. However, Loxoconcha cotoensis sp. nov. differs from L. pulchra in having a prominent eye tubercle, straight dorsal margin, and trifurcated muri. The male copulatory organ of L. cotoensis sp. nov. differs from this because of its funeralbell-like clasping apparatus, ox-shaped distal lobe, and copulatory duct being short with a tapered distal end (see Nakao and Tsukagoshi, 2002, about the copulatory organ of L. pulchra). Focused on their habitat, L. taiwanensis is reported below the depth of $20 \mathrm{~m}$ in the Yellow Sea and the Bohai Sea (Wang et al., 1988). L. pulchra is abundant in sandy tidal flats in Japan (Nakao and Tsukagoshi, 2002). The depth of the locality of $L$. cotoensis is 2.5 to $4 \mathrm{~m}$. Thus, some species that resemble $L$. cotoensis show annidations that depend on the water depth. 

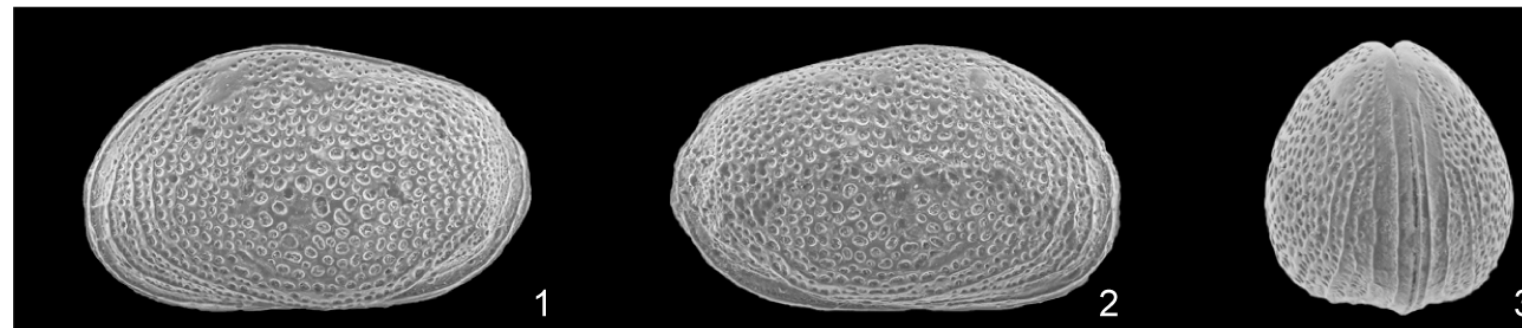

3
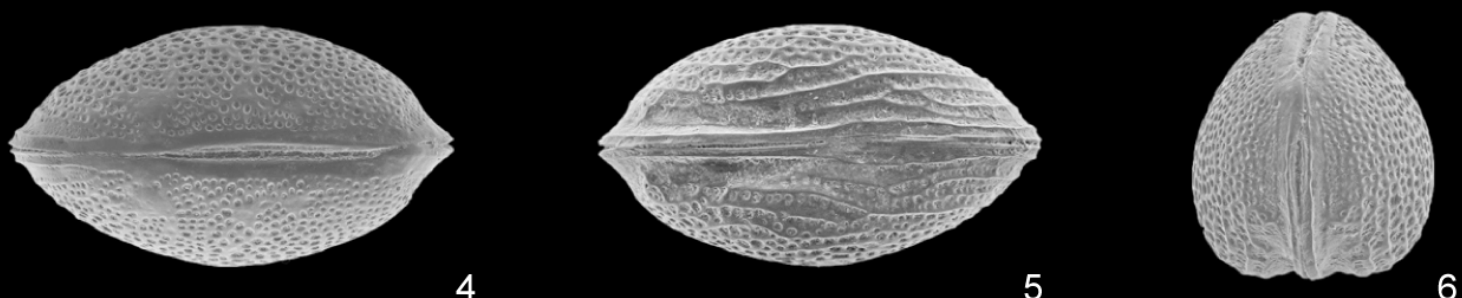

5

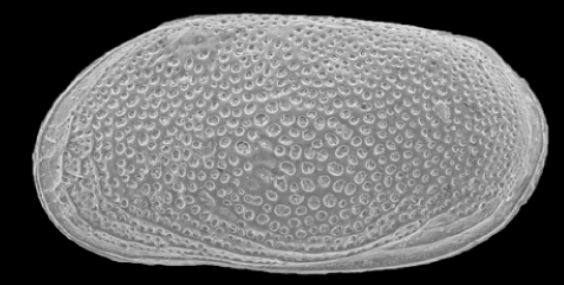

7

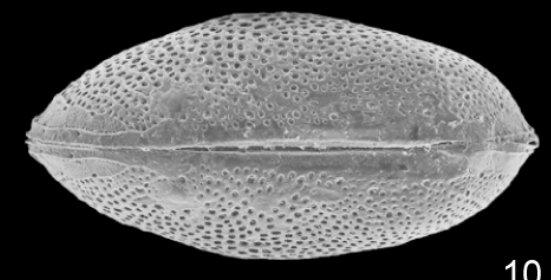

10

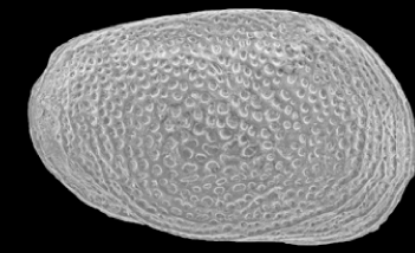

13

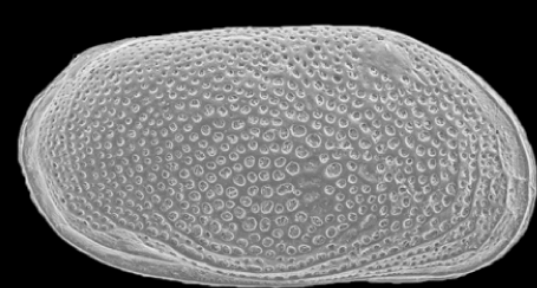

8



11

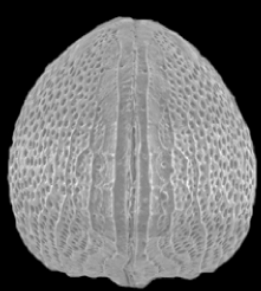

9

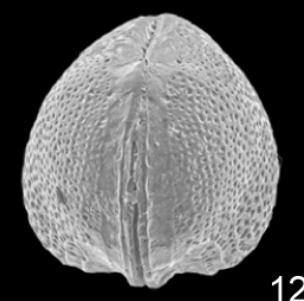

12

Figure 6. Scanning electron photomicrographs of the carapaces of Loxoconcha cotoensissp. nov. female (VNMN.0099) (1-6); male (VNMN.0100) (7-12); female A-1 (VNMN.0101) (13) and male A-1 (VNMN.0102) (14) from the Co To Islands, northeastern Vietnam: (1, 7) left lateral view; $(2,8)$ right lateral view; $(3,9)$ anterior view; $(4,10)$ dorsal view; $(5,11)$ ventral view; $(6,12)$ posterior view. $(13)$, right lateral view, male, A-1; (14), right lateral view, female, A-1. Scale bar is $100 \mu \mathrm{m}$. 




Figure 7. The valve and the soft parts of Loxoconcha cotoensis sp. nov. (1-2) internal view of female left valve (VNMN.0103); (1) scanning electron photomicrographs; (2) camera lucida drawing; (3-10) camera lucida drawing of soft parts of the male - (3) antennule; (4) antenna; (6b) distal part of maxillula; (7) first thoracic leg; (8) second thoracic leg; (9) third thoracic leg; (10) copulatory organ (VNMN.0104, 0105, 0106). Scale A, $100 \mu \mathrm{m}$ for $1-2$; scale B, $100 \mu \mathrm{m}$ for (3-10). 
Data availability. The data used are available upon request to the corresponding author.

Supplement. The supplement related to this article is available online at: https://doi.org/10.5194/jm-38-97-2019-supplement.

Author contributions. TK, HDD, HBN, HTT, and MTN conducted field survey. SN and GT prepared the manuscript with contributions from all co-authors.

Competing interests. The authors declare that they have no conflict of interest.

Acknowledgements. This work was supported by the Grantin-Aid for Science Research from the Ministry of Education of Science of the Government of Japan (no. 16K05592 to GT and no. 16K05593 to TK) and Project for Collecting Paleontological Specimens in Vietnam (BSTMV.28/15-18 to Dinh). We would like to thank Editage (http://www.editage.jp, last access: 14 May 2018) for the English language editing. We thank Ruby Chiu and one anonymous referee as well as Handling Editor (Thomas M. Cronin) for helpful suggestions.

Review statement. This paper was edited by Thomas M. Cronin and reviewed by Ruby Chiu and one anonymous referee.

\section{References}

Athersuch, J., Horne, D. J., and Whittaker, J. E.: Marine and Brackish Water Ostracods, in: Synopses of the British Fauna (New Series), edited by: Kermack, D. M. and Barnes, R. S. K., Avon, The Bath Press, 1-343, 1989.

Brady, G. S.: On new or imperfectly known species of marine Ostracoda, Transactions of the Zoological Society of London, 5, 359-393, 1866.

Brady, G. S.: Contributions to the study of the Entomostraca II, Marine Ostracoda from the Mauritius, Ann. Mag. Nat. His., 4, 178184,1868

Brady, G. S.: Description of Ostracoda, in: Les Fonds de la Mer, Part 1, edited by: Folin, L. D. and Périer, L., 155-159, 1869.

Brady, G. S.: Report on the Ostracoda dredged by H.M.S. Challenger during the Years 1873-1876, in: Report on the scientific results of the voyage of H.M.S. Challenger, Zoology, 1, 1-184, 1880.

Brady, G. S.: On Ostracoda collected by H. B. Brady, in: the South Sea Islands, Transactions of the Royal Society of Edinburgh: Earth Sciences, edited by: Brady, G. S., 35, 489-525, 1890.

Cai, H.: Distribution of Ostracoda in the northeastern waters of the South China Sea, Tropic Oceanology, 1, 42-57, 1982 (in Chinese with English abstract)

Cai, H.: Ostracoda in sediments from the north continental shelf of South China Sea, Tropic Oceanology, 7, 19-27, 1988 (in Chinese with English abstract).
Fauzielly, L., Irizuki, T., and Sampei, Y.: Spatial distribution of Recent ostracode assemblages and depositional environments in Jakarta Bay, Indonesia, with to environmental factors, Paleontol. Res., 16, 267-281, https://doi.org/10.2517/1342-8144-16.4.267, 2013.

Gou, Y.: Recent Ostracoda from Hainan Island, South China Sea, Cour. For. Senkenbg., 123, 19-36, 1990.

Hammer, Ø.: PAST: PAleontological STatistics Version 3.01, http: //folk.uio.no/ohammer/past/ (last access: 5 May 2018), 2013.

Hanai, T.: Studies on the Ostracoda from Japan. 1 - Subfamily Leptocytherinae, new subfamily, Journal of the Faculty of Science, Tokyo University, Section 2, 10, 431-468, 1957a.

Hanai, T.: Studies on the Ostracoda from Japan. 3 - Subfamily Cytherurinae G. W. Müller (emend. G. O. Sars) and Cytheropterinae, new subfamily, Journal of the Faculty of Science, Tokyo University, Section 2, 11, 11-36, $1957 \mathrm{~b}$.

Hanai, T.: Studies on the Ostracoda from Japan. 4 - Family Cytherideidae, Sars, 1925, Journal of the Faculty of Science, Tokyo University, Section 2, 11, 291-308, 1959a.

Hanai, T.: Studies on the Ostracoda from Japan. 5 - Subfamily Cytherinae Dana, 1852, Journal of the Faculty of Science, Tokyo University, Section 2, 11, 409-418, 1959b.

Hanai, T., Ikeya, N., and Yajima, M.: Checklist of Ostracoda from Southeast Asia, The university Museum, The University of Tokyo, 17, 1-236, 1980.

Hartmann, G.: Zur Kenntnis des Eulitorals der afrikanischen Westkueste zwischen Angola und Kap der Guten Hoffnung und der afrikanischen Ostkueste von Suedafrika und Mocambique unter besonderer Beruecksichtigung der Polychaeten und Ostracoden, Teil 3: Die Ostracoden des Unte, edited by: Hartmann-Schroeder, G. and Hartmann, G., Mitteilungen aus dem Hamburgischen Zoologischen Museum und Institut, 69, 229-521, 1974 (in German).

Hartmann, G.: Zur Kenntnis des Eulitorals der australischen Küsten unter besonderer Berücksichtigung der Polychaeten und Ostracoden. Teil 1: Die Ostracoden der Ordnung Podocopida G. W. Müller,1894 der tropisch-subtropischen Westküste Australiens (zwischen Derby und Perth, Mitteilungen aus dem Hamburgischen Zoologischen Museum und Institut, 75, 63-219, 1978 [in German with English abstract].

Hartmann, G.: Zur Kenntnis des Eulitorals der australischen Kusten unter besonderer Berucksichtigung der Polychaeten und Ostracoden, Teil 7, Die Ostracoden der Ordnung Podocopida G. W. Müller, 1894 der subtropisch-tropischen Ostküste Australiens (zwischen Eden im Süden und Heron-Island im Norden), Mitteilungen aus dem Hamburgischen Zoologischen Museum und Institut, 78, 97-149, 1981 (in German with English abstract).

Herrig, E.: Newe Ostracoden-Arten aus dem Plio-/Pleistozän der Sozialistischen Republik Vietnam, Teil I, Z. Geol. Wissenschaft., 4, 1413-1427, 1976 (in German).

Herrig, E.: Newe Ostracoden-Arten aus dem Plio-/Pleistozän der Sozialistischen Republik Vietnam, Teil II, Z. Geol. Wissenschaft., 5, 203-211, 1977a (in German).

Herrig, E.: Ostracoden aus dem Plio-/Pleistozän der Sozialistischen Republik Vietnam, Teil I, Z. Geol. Wissenschaft., 5, 1153-1167, 1977b (in German).

Herrig, E.: Ostracoden aus dem Plio-/Pleistozän der Sozialistischen Republik Vietnam, Teil II, Z. Geol. Wissenschaft., 5, 1253-1267, 1977c (in German). 
Herrig, E.: Ostracoden aus dem Plio-/Pleistozän der Sozialistischen Republik Vietnam, Teil III, Z. Geol. Wissenschaft., 6, 79-95, 1978 (in German).

Horn, H. S.: Measurement of "Overlap" in Comparative Ecological Studies, Am. Nat., 100, 419-424, 1966.

Hou, Y., Chen, T., Yang, H., Ho, J., Zhou, Q., and Tian, M.: Cretaceous-Quaternary ostracode fauna from Jiangsu, Geological Publishing House, Beijing, 1-386, 1982.

Howe, H. V. and McKenzie, K. G.: Recent marine Ostracoda (Crustacea) from Darwin and north-Western Australia, Monograph Series of the Northern Territory, Museum of Arts and Sciences, 3, $1-50,1989$.

$\mathrm{Hu}, \mathrm{C}$. : Studies on ostracod faunas from the Hengchun Limestone (Pleistocene), Hengchun area, southern Taiwan, Quarterly Journal of The Taiwan Museum, 35, 171-195, 1982.

$\mathrm{Hu}, \mathrm{C}$. and Tao, J.: Studies on the ostracod fauna of Taiwan and its adjacent seas, National Taiwan Museum Special Publication Series. 13 (parts 1 and 2), 1-910, 2008 (In Chinese).

Ikeya, N. and Kato, K.: The life history and culturing of Xestoleberis hanaii (Crustacea, Ostracoda), Hydrobiologia, 419, 149159, https://doi.org/10.1023/A:1003931901501, 2000.

Irizuki, T., Takata, T., and Ishida, K.: Recent Ostracoda from Urauchi Bay, Kamikoshiki-jima Island, Kagoshima Prefecture, southwestern Japan, Laguna, 13, 13-28, 2006.

Irizuki, T., Seto, K., and Nomura, R.: The impact of fish farming and bank construction on Ostracoda in Uranouchi Bay on the Pacific coast of southwest Japan - Faunal changes between 1954 and 2002/2005, Paleontol. Res., 12, 283-302, https://doi.org/10.2517/1342-8144-12.3.283, 2008.

Ishizaki, K.: Ostracodes from Uranouchi Bay, Kochi Prefecture, Japan, Science Reports of the Tohoku University, Sendai, Second Series, Geology, 40, 1-45, 1968.

Ishizaki, K.: Ostracodes from Aomori Bay, Aomori Prefecture, Northeast Honshu, Japan, Science Reports of the Tohoku University, Sendai, Second Series, Geology, 43, 59-97, 1971.

Ishizaki, K. and Kato, M.: The basin development of the Diluvium Furuya Mud Basin, Shizuoka Prefecture, Japan, in: Progress in Micropaleontology, edited by: Takayanagi, Y. and Saito, T., New York, Micropaleontology Press, 118-143, 1976.

Jellinek, T.: Zür Ökologie und Systematik rezenter Ostracoden aus dem Bereich des kenianischen Barriere-Riffs, Senkenbergiana Lethaea, 73, 83-225, 1993.

Kamiya, T.: Morphological and ethological adaptations of Ostracoda to microhabitats in Zostera beds, in: Evolutionary biology of Ostracoda: Its Fundamentals and Applications, edited by: Hanai, T., Ikeya, N., and Ishizaki, K., Kodansha, Tokyo, 303318, 1988.

Kingma, J. T.: Contributions to the knowledge of the youngCaenozoic Ostracoda from the Malayan region, University of Utrecht, Utrecht, 1-118, 1948.

Maddocks, R. F.: Recent ostracodes of the Family Pontocyprididae chiefly from the Indian Ocean, Smithsonian Contributions to Zoology, 7, 1-56, 1969.

Masuma, T. and Yamada, K.: Recent ostracode distributions in $\mathrm{Ku}-$ mihama Bay (brackish lake) in the northern part of Kyoto Prefecture, central Japan, Laguna, 21, 1-14, 2014 (in Japanese with English abstract).

Mostafawi, N.: Rezente Ostracoden aus dem mittleren Sunda-Shelf, zwischen der Malaiischen Halbinsel und Borneo, Senkenber- giana Lethaea, 72, 129-168, 1992 (in German with English abstract).

Mostafawi, N., Colin, J. P., and Babinot, J. F.: An account on taxonomy of ostracodes from recent reefal flat deposits in Bali, Indonesia, Revue de Micropaleontologie, 48, 123-140, https://doi.org/10.1016/j.revmic.2004.12.001, 2005.

Nakao, Y. and Tsukagoshi, A.: Brackish-water Ostracoda (Crustacea) from the Obitsu River estuary, central Japan, Species Diversity, 7, 67-115, 2002.

Nakao, Y., Tanaka, G., and Yamada, S.: Pleistocene and living marine Ostracoda in Shizuoka District, Japan, in: 14th International Symposium on Ostracoda, Guidebook of Excursions, edited by: Ikeya, N., The Organising Committee of ISO 2001, 127-147, 2001.

Okubo, I.: Recent marine Ostracoda in the Inland Sea, Japan, I. Callistocythere pumila Hanai, 1957 and Leguminocythereis bisanensis sp. nov. in the Inland Sea, Japan (Ostracoda), Proceedings of the Japanese Society of Systematic Zoology, 11, 23-31, 1975.

Okubo, I.: On the life history and size of Xestoleberis hanaii, Research Bulletin of Shujitsu Junior College, Okayama, 14, 19-43, 1984.

Ramlan, O. and Noraswana, N. F.: Distribution of Recent Ostracoda in Offshore Sediment Around Pulau Besar, Johor, Sains Malays., 39, 199-207, 2010.

Ruan, P.: Distribution of recent Ostracoda from the coastal zone of Gaode and Weizhou Island, Zhuang Autonomous Region of Guangxi, Acta Oceanol. Sin., 9, 119-134, 1990.

Sars, G. O.: Oversigt af Norges marine Ostracoder, Det Norske Videnskaps-Akademi Forhandlingar, 1865, 1-130, 1866 (in Danish).

Sars, G. O.: An account of the Crustacea of Norway, Volume 9Ostracoda Part 11, 12, Cytheridae, Bergen Museum, Bergen, 177-208, 1925.

Schneider, G. F.: Ostracodes from Quaternary deposits of North Vietnam, Paleontol. J., 5, 259-262, 1971.

Smith, A. J. and Horne, D. J.: Ecology of Marine, Marginal Marine and Nonmarine Ostracodes, in: The Ostracoda, Application in Quaternary Research, edited by: Holmes, J. A. and Chivas, A. R., American Geophysical Union, Washington, DC, 37-64, 2002.

Tabuki, R. and Nohara, T.: The Ostracoda of the Sekisei-sho area, Ryukyu Islands, Japan: A preliminary report on the ostracods from the coral reefs in the Ryukyu Islands, in: Ostracoda and global events, edited by: Whatley, R. C. and Maybury, C., Chapman and Hall, 365-377, 1990.

Tanaka, G.: Recent benthonic ostracod assemblages as indicators of the Tsushima warm current in the southwestern Sea of Japan, Hydrobiologia, 598, 271-284, https://doi.org/10.1007/s10750-0079162-6, 2008.

Tanaka, G. and Nomura, S.: Late Miocene and Pliocene Ostracoda from the Shimajiri Group, Kume-jima Island, Japan: Biogeographical significance of the timing of the formation of backarc basin (Okinawa Trough), Palaeogeogr. Palaeocl., 276, 56-68, https://doi.org/10.1016/j.palaeo.2009.02.023, 2009.

Tanaka, G., Seto, K., and Takayasu, K.: The relationship between environments and ostracode assemblages from Miho Bay to Lake Shinji, Laguna, 5, 81-91, 1998 (in Japanese with English abstract).

Tanaka, G., Komatsu, T., and Phong, N. D.: Recent ostracod assemblages from the northeastern coast of Vietnam and the biogeo- 
graphical significance of the euryhaline species, Micropaleontology, 55, 365-382, 2009.

Tanaka, G., Kaseda, Y., and Ikeya, N.: Reclassification of the genus Hemicytherura (Crustacea, Ostracoda) from Japan and the surrounding regions, Bulletin of the Gunma Museum of Natural History, 15, 19-42, 2011a.

Tanaka, G., Komatsu, T., Saito, Y., Phong, N. D., and Lan, V. Q.: Temporal changes in ostracod assemblages during the past 10,000 years associated with the evolution of the Red River delta system, northeastern Vietnam, Mar. Micropaleontol., 81, 77-87, https://doi.org/10.1016/j.marmicro.2011.08.001, 2011 b.

Tanaka, H., Le, D. D., Higashi, R., and Tsukagoshi, A.: A new interstitial ostracod species of the genus Paracobanocythere from Vietnam, with mitochondrial COI sequence data of three Asian species, Zookeys, 559, 17-33, https://doi.org/10.3897/zookeys.559.6751, 2016.

Teeter, J. W.: Geographic distribution and dispersal of some Recent shallow-water marine Ostracoda, Ohio J. Sci., 73, 46-54, 1973.

Teeter, J. W.: Distribution of Holocene marine Ostracoda from Belize, American Association of Petroleum Geologists Studies in Geology, 2, 400-499, 1975.

Titterton, R. and Whatley, R. C.: The provincial distribution of shallow water Indo-Pacific marine Ostracoda: Origin, antiquity, dispersal routes and mechanisms, in: Evolutionary biology of Ostracoda: Its fundamentals and applications, edited by: Hanai, T., Ikeya, N., and Ishizaki, K., Kodansha, Tokyo, 759-786, 1988.

Wang, P., Zhang, L., Zhao, Q., Min, Q., Bian, Y., Zheng, L., Cheng, X., and Chen, R.: Foraminifera and Ostracoda in bottom sediments of the East China Sea, Beijing, 1-438, 1988 (in Chinese).

Warne, M., Whatley, R. C., and Blagden, B.: Ostracoda from Lee Point on Shoal Bay, Northern Australia: part 3, Podocopina (Cytheracea), Revista Española de Micropaleontología, 38, 103167, 2006.

Whatley, R. C. and Keeler, N.: Recent Ostracoda from Reunion Island, Southwestern Indian Ocean, Revue de Micropaléontologie, 32, 63-84, 1989.

Whatley, R. C. and Zhao, Q.: Recent Ostracoda of Malacca straits, part I, Revista Española de Micropaleontología, 19, 327-366, 1987a.

Whatley, R. C. and Zhao, Q.: On Cathaycythere reticulata Whatley and Zhao gen. et sp. nov., Stereo-Atlas of Ostracod Shells, 14, $1-4,1987 b$.
Whatley, R. C. and Zhao, Q.: Recent Ostracoda of Malacca straits, part II, Revista Española de Micropaleontología, 20, 5-37, 1988.

Whatley, R. C. and Zhao, Q.: On Paracathaycythere costaereticulata Whatley \& Zhao gen. et sp. nov., Stereo-Atlas of Ostracod Shells, 18, 93-96, 1991.

Witte, L. and Harten van, D.: Polymorphism, biogeography and systematics of Kotoracythere inconspicua (Brady, 1880) (Ostracoda: Pectocytheridae), J. Biogeogr., 18, 427-436, 1991.

Yajima, M.: Quaternary Ostracoda from Kisarazu near Tokyo, Transactions and Proceedings of the Palaeontological Society of Japan New Series, 112, 371-409, 1978

Yajima, M.: Late Pleistocene Ostracoda from the Boso Peninsula, central Japan, Bulletin University Museum University of Tokyo, 20, 141-227, 1982

Yamada, K., Terakura, M., and Tsukawaki, S.: The impact on bottom sediments and ostracods in the Khlong Thom River mouth following the 2004 Indian Ocean Tsunami, Paleontol. Res., 18, 104-117, https://doi.org/10.2517/2014PR011, 2014.

Yasuhara, M., Iwatani, H., Hunt, G., Okahashi, H., Kase, T., Hayashi, H., Aguilar, Y. M., Fernando, A. G. S., and Renema, W.: Cenozoic dynamics of shallow-marine biodiversity in the Western Pacific, J. Biogeogr., 44, 567-578, https://doi.org/10.1111/jbi.12880, 2017.

Zhao, Q.: Recent Ostracoda from the coast zone of the East China Sea and the Yellow Sea, Marine Geology and Quaternary Geology, 4, 45-57, 1984 (in Chinese with English abstract).

Zhao, Q. and Wang, P.: Distribution of modern Ostracoda in the shelf seas off China, in: Evolutionary biology of Ostracoda: Its fundamentals and applications, edited by: Hanai, T., Ikeya, N., and Ishizaki, K., Kodansha, Tokyo, 805-821, 1988.

Zhao, Q. and Whatley, R. C.: Recent Podocopid Ostracoda of Sedili River and Jason Bay, southeastern Malay Peninsula, Micropaleontology, 35, 168-187, 1989.

Zheng, Z.: A comprehensive ecological and palaeoecological study of the sedimentary organisms in the northern and eastern areas of the South China Sea, Hubei Science and Technical Press, Beijing, 1-175, 1994 (in Chinese with English abstract).

Zhou, B.: Recent Ostracode Fauna in the Pacific off Southwest Japan, Memoirs of the Faculty of Science, Kyoto University, Ser. Geol. Mineral., 57, 21-98, 1995. 